INTERNATIONAL MONETARY FUND

\title{
CENTRAL AFRICAN REPUBLIC
}

\section{Joint World Bank-IMF Debt Sustainability Analysis}

July 2019

Prepared jointly by the staffs of the International Development Association (IDA) and the International Monetary Fund (IMF)

Approved by Marcello Estevão (IDA) and Annalisa Fedelino and Martin Sommer (IMF)

\begin{tabular}{|l|l|}
\hline \multicolumn{2}{|c|}{ Central African Republic: Joint Bank-Fund Debt Sustainability Analysis } \\
\hline Risk of external debt distress & High \\
\hline Overall risk of debt distress & High \\
\hline Granularity in the risk rating & Sustainable \\
\hline Application of judgment & No \\
\hline
\end{tabular}

The Central African Republic (C.A.R.) remains at high risk of external debt distress and overall high risk of debt distress under the revised Debt Sustainability Framework (DSF), unchanged from the 2018 DSA. Solvency indicators (the present values of the external public and publicly guaranteed debt-to-GDP and debt-to-exports ratios) remain below their relevant thresholds in the baseline scenario. However, liquidity indicators (debt service-to-exports and debt service-torevenue ratios) breach their thresholds in the baseline scenario. Further considerations support the high-risk assessment: the debt indicators are sensitive to standard stress tests; macroeconomic projections are highly uncertain in a volatile security environment; and sizeable contingent liabilities, notably related to the large stock of unaudited potential domestic arrears and the limited financial information available on state-owned enterprises, could materialize. C.A.R.'s debt sustainability is also sensitive to a deterioration of the financing mix. A tailored scenario in which grant financing (of 2 percent of GDP) is replaced by concessional external debt-financing from 2021 onwards would worsen debt sustainability considerably. This shows that the government's investment program requires grant financing, with concessional debt financing to be considered in exceptional cases. 


\section{PUBLIC DEBT COVERAGE}

1. The coverage of public sector debt is in line with the previous DSA, exhibiting some gaps. Information is available on the central government's contractual debt obligations. State and local governments do not borrow, there are no social security funds guaranteed by the public sector, and the government has not guaranteed other debt. However, sizeable contingent liabilities could materialize: (i) the authorities shared with staff a list of potential additional domestic payment arrears, which have yet to be audited, and (ii) little information is available on the financial situation and domestic debt of state-owned enterprises (SOEs), including the three big utilities for water (SODECA), communication (SOCATEL), and energy (ENERCA). The authorities are taking specific steps to improve financial oversight of SOEs, which should lead to better debt coverage going forward. They submitted to parliament a new legal framework governing SOEs and have reorganized the Ministry of Finance. They also committed to audit the identified potential domestic arrears by end-September 2019. The debt unit is being strengthened through training and better IT systems supported by development partners.

\section{The tailored test of contingent liabilities assumes a shock of $\mathbf{1 5}$ percent of GDP.} This significant amount reflects the uncertainty about additional domestic arrears, nonguaranteed SOE debt, and financial market risks. The shock from domestic arrears is set at 5 percent of GDP to factor in past and persisting shortcomings in the country's public expenditure management systems. The contingent liabilities shock from SOE debt is set at 5 percent of GDP to reflect heightened risks associated with non-guaranteed SOE debt and potential expenditure arrears. The financial market risk shock is kept at the minimum default value of 5 percent of GDP given the small size and depth of the financial sector in C.A.R.

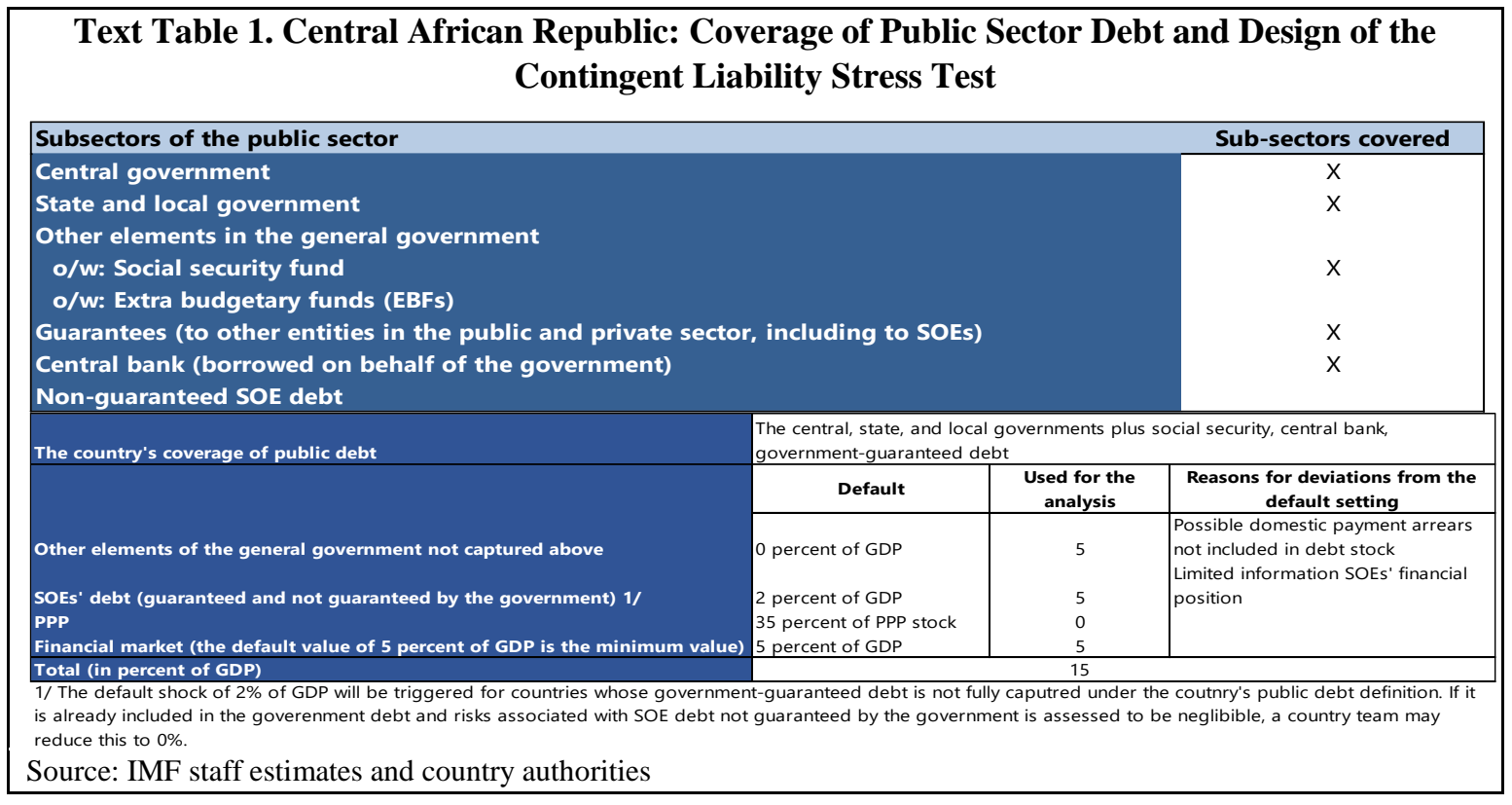




\section{BACKGROUND}

3. C.A.R.'s public and publicly guaranteed (PPG) debt is declining. It stood at 48.8 percent of GDP at end-2018 (down from 49.4 percent of GDP at end-2017), with external debt amounting to 34.9 percent of GDP (33.3 percent of GDP at end-2017). ${ }^{1}$ Debt indicators deteriorated significantly in the wake of the 2013 crisis when GDP collapsed, and domestic and external arrears accumulated. Conditions have improved since, supported by economic recovery, stronger revenue mobilization, arrears clearance and limited new borrowing (Text Figure 1). Since the crisis, C.A.R. has contracted new loans from Saudi Arabia (2015 project loan for disbursements of up to US\$75 million; grant element 49.4 percent), African Development Bank (2017 budget support loan of US\$15 million, grant element 60.2 percent), BADEA (2018 project loan for disbursements of up to US\$13 million, grant element 50.2 percent), and the IMF $\quad(\mathrm{ECF}$ and RCF disbursements totaling SDR 133.12 million, grant element 30.5 percent).

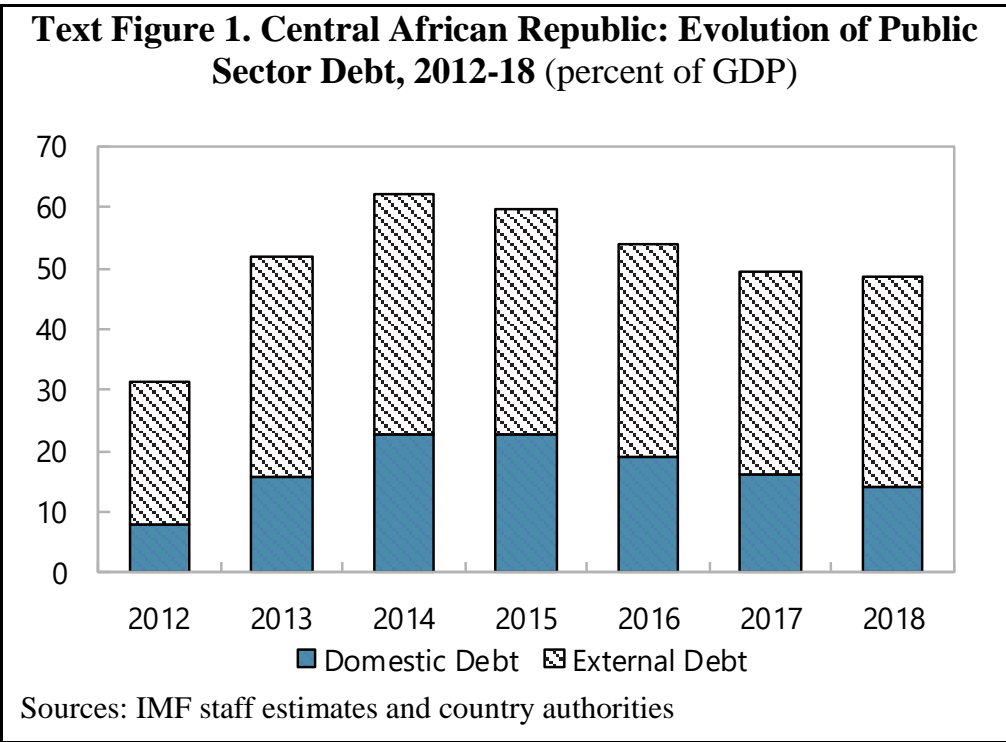

4. Pre-HIPC arrears and debt owed to multilateral creditors account for the bulk of external debt (Text Table 2). Multilateral creditors, mainly the IMF and the World Bank, hold almost half of the external debt. Bilateral debt amounts to 7.2 percent of GDP, with India, China and Congo being the main creditors. Pre-HIPC arrears are owed to Non-Paris Club creditors (Argentina, Equatorial Guinea, Iraq, Libya, and Taiwan, Province of China). The average nominal interest rate stood at 0.6 percent for external debt, reflecting the preponderance of concessional borrowing. Half of the domestic debt consists of statutory and exceptional advances from the Central Bank, which have been consolidated into one loan to be repaid from 2022 onwards, in line with regional arrangements. The remainder mainly includes officially recognized arrears amounting to 4.7 percent of GDP.

5. The composite indicator signals a weak debt-carrying capacity (Text Table 3). Institutions in C.A.R. are weakened by persistent fragility. The composite indicator, a proxy

\footnotetext{
${ }^{1}$ External debt is defined on a residency basis with the exception of BEAC advances, which are considered domestic debt as in the last DSA for C.A.R. Mechanically, the CFAF-denominated debt held by the BEAC would weaken the external debt sustainability indicators if they were considered external debt, but the risk from this debt is lower than foreign currency denominated debt owing to the lack of currency risk, strong institutional ties, and the relative ease of rescheduling. All outstanding T-bills are held by domestic banks and included in domestic debt.
} 
for debt-carrying capacity, is comprised of the real growth rate, import coverage of reserves, remittances, world growth, and the World Bank's CPIA. C.A.R. has a score of 2.42, well below the floor (2.69) for medium debt-carrying capacity.

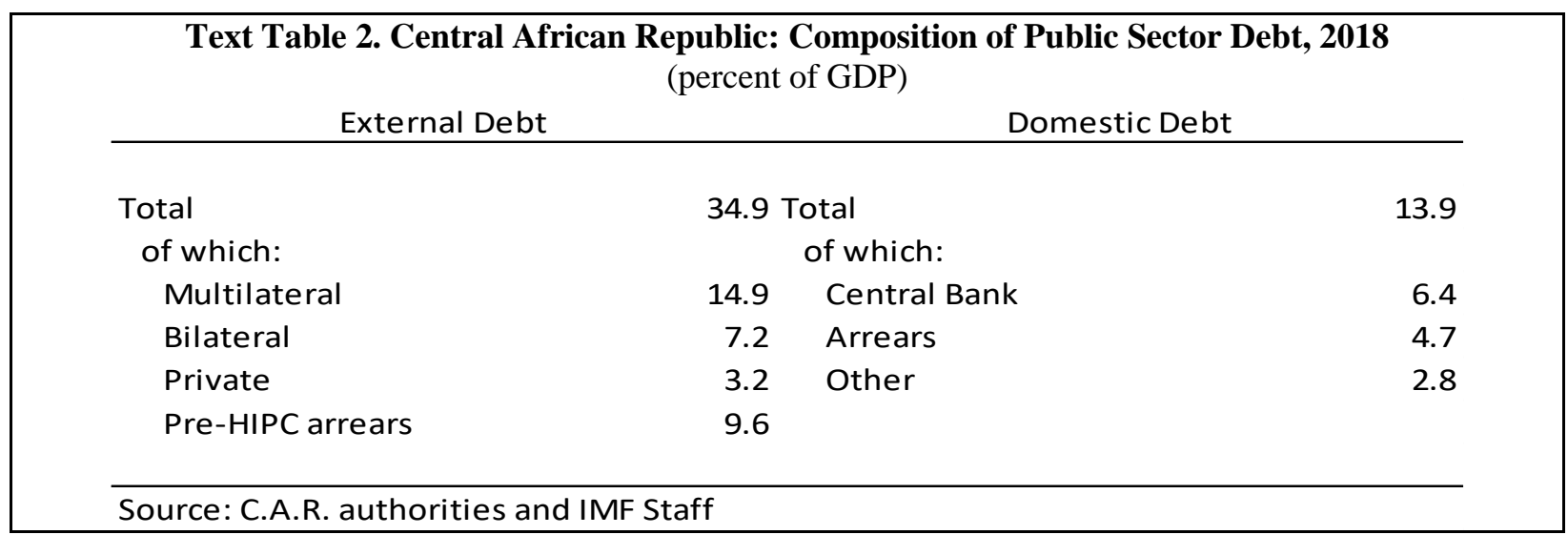

\begin{tabular}{|c|c|c|c|c|c|}
\hline \multicolumn{6}{|c|}{ Text Table 3. Central African Republic: Calculation of composite indicator and thresholds } \\
\hline \multirow{7}{*}{$\begin{array}{c}\text { Components } \\
\text { CPIA } \\
\text { Real growth rate } \\
\text { (in percent) } \\
\text { Import coverage of reserves } \\
\text { (in percent) } \\
\text { Import coverage of reserves }{ }^{\wedge} 2 \\
\text { (in percent) } \\
\begin{array}{l}\text { Remittances } \\
\text { (in percent) } \\
\text { World economic growth } \\
\text { (in percent) }\end{array}\end{array}$} & Coefficients (A) & $\begin{array}{c}10 \text {-year average } \\
\text { values (B) }\end{array}$ & $\begin{array}{l}\text { CI Score components } \\
\left(A^{*} B\right)=(C)\end{array}$ & \multicolumn{2}{|c|}{$\begin{array}{c}\text { Contribution of } \\
\text { components }\end{array}$} \\
\hline & 0.385 & 2.471 & 0.95 & & $39 \%$ \\
\hline & 2.719 & 3.272 & 0.09 & & $4 \%$ \\
\hline & 4.052 & 32.644 & 1.32 & & $55 \%$ \\
\hline & -3.990 & 10.657 & -0.43 & & $-18 \%$ \\
\hline & 2.022 & 0.097 & 0.00 & & $0 \%$ \\
\hline & 13.520 & 3.579 & 0.48 & & \\
\hline CI Score & & & 2.42 & & $100 \%$ \\
\hline Cl rating & & & Weak & & \\
\hline EXTERNAL debt burden thresholds & Weak & Medium & & irong & \\
\hline PV of debt in \% of & & & & & \\
\hline Exports & 140 & 180 & & 240 & \\
\hline GDP & 30 & 40 & & 55 & \\
\hline Debt service in $\%$ of & & & & & \\
\hline Exports & 10 & 15 & & 21 & \\
\hline Revenue & 14 & 18 & & 23 & \\
\hline TOTAL public debt benchmark & & & Weak & & Strong \\
\hline PV of total public debt in percent of $G$ & GDP & & 35 & & 70 \\
\hline
\end{tabular}




\section{UNDERLYING MACROECONOMIC ASSUMPTIONS}

6. Macroeconomic assumptions have been updated since the 2018 DSA. The medium-term scenario is consistent with the macroeconomic framework underpinning the ECF-supported program (Text Table 4).

- Revised national accounts data led to an upward revision of the 2017 nominal GDP by 7 percent. Staff estimates that real GDP growth in 2018 was 3.8 percent and that growth in 2019 will reach 4.5 percent. Higher medium-term (2020-24) growth of 5 percent reflects the assumption of further catch-up to the pre-crisis level of GDP. In the long run (202539), a 3.4 percent growth is assumed-unchanged from the 2018 DSA. This implies modest

per-capita GDP growth as population growth is estimated at about 2.5 percent.

- The fiscal scenario has been updated to reflect significant additional grant financing in the short term. Budget support grants in 2019-20 are expected to reach a total of 9.7 percent of GDP, significantly higher than the 4.6 percent of GDP assumed at the time of the 2018 DSA. Domestic revenues are assumed to follow a gradual upward trend, reaching 14 percent of GDP at the end of the projection period. Primary spending has been also adjusted to incorporate the revised 2019 budget, reflecting higher spending of 1 percent of GDP. In the first five years, a small primary surplus is expected amid substantial grant financing, which would then turn into a deficit of 1.2 percent of GDP over the long run as grant financing gradually declines.

- External sector variables remain broadly unchanged. The current account balance is expected to improve over time driven by a gradual decline of imports from exceptionally high post-crisis levels. The export of goods and services-to-GDP ratio is expected to decline somewhat initially as the domestic recovery outpaces export growth before rising back to about 15 percent of GDP. Current transfers are expected to decline and FDI to increase gradually from a low level. Overall, it is expected that the non-interest current account deficit will reach 3 percent of GDP in the long run.

- After increasing sharply in the short run, budget grants are assumed to decline in the long run, from an average 7.4 percent of GDP during 2019-24 to 2 percent of GDP by $2039 .{ }^{2}$ The financing needs in the short run are covered by deposit withdrawals while it is assumed that 80 percent of longer-term needs would be covered through external concessional borrowing - with a gradually decreasing degree of concessionality - and the remaining 20 percent through domestic borrowing.

\footnotetext{
${ }^{2}$ This assumption is consistent with multilateral development institutions providing support in the form of a mix of grants and concessional financing. Even if C.A.R.'s risk rating was to improve, a substantial share of financing would likely be provided in the form of grants. However, to further illuminate the sensitivity of debt sustainability to financing assumptions, staff has prepared a tailored scenario which substitutes 2 percent of GDP in grant financing with concessional loans from 2021 onwards.
} 


\begin{tabular}{|c|c|c|c|c|}
\hline \multicolumn{5}{|c|}{ Text Table 4. Central African Republic: Macroeconomic Assumptions } \\
\hline & \multicolumn{2}{|c|}{ DSA-18 } & \multicolumn{2}{|c|}{ DSA-19 } \\
\hline & $\begin{array}{r}2019-23 \\
\text { average }\end{array}$ & $\begin{array}{r}2024-2038 \\
\text { average }\end{array}$ & $\begin{array}{r}2019-24 \\
\text { average }\end{array}$ & $\begin{array}{r}2025-2039 \\
\text { average }\end{array}$ \\
\hline & \multicolumn{2}{|c|}{$(\%$ of GDP) } & \multicolumn{2}{|c|}{$(\%$ of GDP) } \\
\hline GDP growth (percent) & 5.0 & 3.4 & 4.9 & 3.4 \\
\hline GDP deflator (percent) & 3.1 & 3.3 & 2.6 & 2.8 \\
\hline Non-interest current account balance & -6.0 & -2.8 & -4.8 & -2.8 \\
\hline Exports & 13.9 & 14.0 & 14.8 & 14.6 \\
\hline Primary balance & 0.6 & -1.9 & 0.4 & -1.0 \\
\hline Revenues & 16.6 & 13.3 & 18.2 & 16.6 \\
\hline
\end{tabular}

7. The newly added realism tools do not flag significant risks around the baseline scenario. Both external and public PPG debt projections are in line with the 2018 DSA. Factors contributing to debt dynamics appear broadly in line with historical contributions. External and public PPG debt are higher than expected at the time of the 2012 DSA, which is mainly related to the impact of the 2013 crisis. Unexpected changes in external and public debt are close to the median for all LICs. The envisaged fiscal path is well in line with the historical performance and the experience in other LIC countries. It is also worth noting that, in the case of C.A.R., changes in the primary balance are not always a good indicator to gauge the impact of fiscal policy. While the primary balance is expected to improve substantially (owing to the significant increase in external grants, which will be only partly spent), fiscal policy is likely to prove expansionary (owing to the increase in spending).

8. Standardized stress tests highlight debt sustainability's vulnerability to shocks. Default settings have been used for these tests. The contingent liability stress test is based on the quantification of contingent liabilities discussed above. The commodity price shock is not applicable. Commodity exports dominate goods exports, with a share of about 70 percent. However, C.A.R.'s significant services exports - driven by service delivery to the non-resident public sector (e.g. embassies and international organizations)—bring commodity exports below the 50 percent of goods and services export threshold.

9. A tailored scenario, assuming worse external financing terms than in the baseline, shows that room for additional borrowing is limited. C.A.R. is highly dependent on external grant financing for budget support and project implementation. Grant financing is projected to reach 11 percent of GDP in 2019, and it is assumed to decline to 6.1 percent of GDP by 2024 and 2 percent of GDP by 2039. In light of the country's very low per-capita income, persistent fragility, and weak institutions, it is likely that development partners will continue to provide subtantial parts of their support in the form of grants. However, it cannot be excluded that less grant financing than assumed will be available in the medium and long term. To simulate such a deterioration of external financing terms, staff has developed a scenario in which grant financing is reduced by 2 percent of GDP compared to the baseline from 2021 onwards, with concessional financing (grant element of 35 percent) substituting for the "lost" grants. 


\section{DEBT SUSTAINABILITY}

\section{External Debt Sustainability Analysis}

10. Solvency indicators remain well below their thresholds in the baseline scenario (Figure 1). In the baseline scenario, the present values (PV) of the external PPG debt-to-GDP and debt-to-exports ratios do not breach their thresholds and decline from their initial level over the projection period. The standardized stress test of lower nominal export growth leads to a temporary breach of the PV of the external debt-to-exports ratio. ${ }^{3}$ The PV of the external debt-to-GDP ratio stays below the thresholds even under the most extreme standardized stress test (a combination of a shock to growth, the primary balance, exports, other (non-debt creating) flows, and depreciation). Setting key variables to their historical average would result in a clear upward trend of the debt ratio.

11. Liquidity indicators temporarily breach their thresholds in the baseline scenario. The external debt service-to-exports ratio breaches the threshold between 2024 and 2026, driven by a significant but temporary uptick of debt service during that period related to the end of the grace period of a loan as well as significant repayments to the Fund. The trajectory of the external debt service-to-revenue ratio is similar but only breaches its threshold in 2025 by a marginal amount. Standardized shocks to exports and growth as well as the historical scenario lead to significant and persistent breaches of the external debt service-to-exports ratio and external debt service-to-revenue ratios.

12. The tailored scenario demonstrates the vulnerability of debt sustainability to lower grant financing. Replacing 2 percent of GDP of grant financing with concessional financing from 2021 onwards would set indicators for debt sustainability on an upward trajectory. Both the PV of the external debt-to-GDP ratio and the PV of the external debt-toexports ratio would be on an increasing trend and breach their respective thresholds within the ten-year projection period. The breaches of the external debt service-to-exports ratio and external debt service-to-revenue ratio would become more pronounced and persistent than in the baseline scenario.

\section{Public Debt Sustainability Analysis}

13. The total PPG debt indicator remains well below its benchmark in the baseline scenario (Figure 2). In addition, the PV of the debt-to-revenue ratio is declining over the projection period. The debt-service-to-revenue and grants ratio is high at the beginning of the projection period with almost 20 percent reflecting significant repayments of domestic arrears. After a significant decline, it is set to rise until 2025 reflecting the start of repayments of exceptional and statutory advances to BEAC and higher external debt service payments. A standardized shock to growth would trigger a breach of the treshold for the PV of the

\footnotetext{
${ }^{3}$ The shock assumes nominal export growth of one standard deviation below its historical average in the second and third year of the projection period.
} 
debt-to-GDP ratio and lead to a significant increase of the PV of the debt-to-revenue ratio. ${ }^{4}$ It is also worth noting that public debt indicators could worsen due to contingent liabilities. An important stock of unverified arrears may lead to additional payment obligations. Adding domestic debt to the analysis does not change the overall risk of debt distress.

\section{CONCLUSION}

14. C.A.R remains at high risk of external debt distress and overall high risk of debt distress. The solvency indicators for the external PPG debt-to-GDP and -to-exports ratios stay below their respective thresholds. However, C.A.R.'s capacity to service debt is severly constrained by its low revenue mobilization and weak export base, with the external debt service-to-export and external debt service-to-revenue ratios breaching their respective thresholds in the baseline scenario. If these breaches are temporary, a number of other considerations support the high-risk assessment. Macroeconomic projections are highly uncertain given the still volatile security environment. Standardized stress tests also underline the sensitivity of the debt indicators to assumptions. Lower export or real GDP growth would trigger a significant deterioration of debt sustainability indicators with multiple threshold breaches. A tailored scenario highlights the vulnerability of debt sustainability to a deterioration in external financing terms, underscoring the importance of grant financing. In addition, sizeable contingent liabilities, notably related to the large stock of unaudited potential domestic arrears and the limited financial information available on SOEs, could materialize.

15. The authorities broadly agreed with this assessment of debt sustainability. They shared the view that C.A.R.'s capacity to service debt is limited and are committed to mobilizing grant financing to cover their financing needs to the extent possible. At the same time, they emphasized that the outlook for debt sustainability has improved recently: overall public debt is on a declining trend and the threshold breaches of the external debt service-toexport and external debt service-to-revenue are temporary and limited in scope. They agreed that there is a need to strengthen debt monitoring, especially by broadening the coverage to SOEs and clarifing the status of unverified domestic arrears. They also intend to further strengthen their capacity to manage debt and improve transparency, including by publishing the 2018 debt report by end-July 2019.

\footnotetext{
${ }^{4}$ The shock assumes real GDP growth of one standard deviation below its historical average in the second and third year of the projection period.
} 
Table 1. Central African Republic: External Debt Sustainability Framework, Baseline Scenario, 2016-39

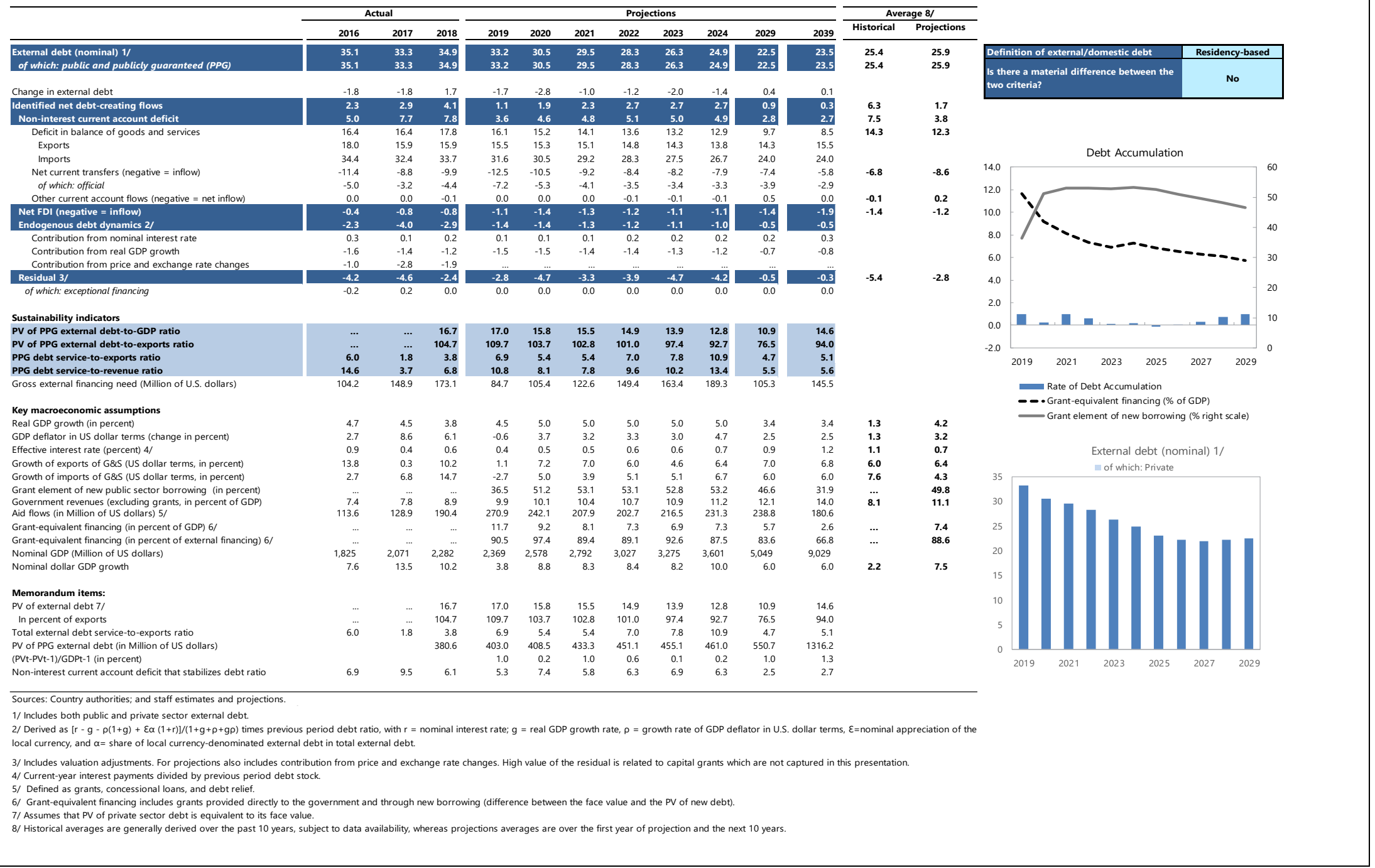




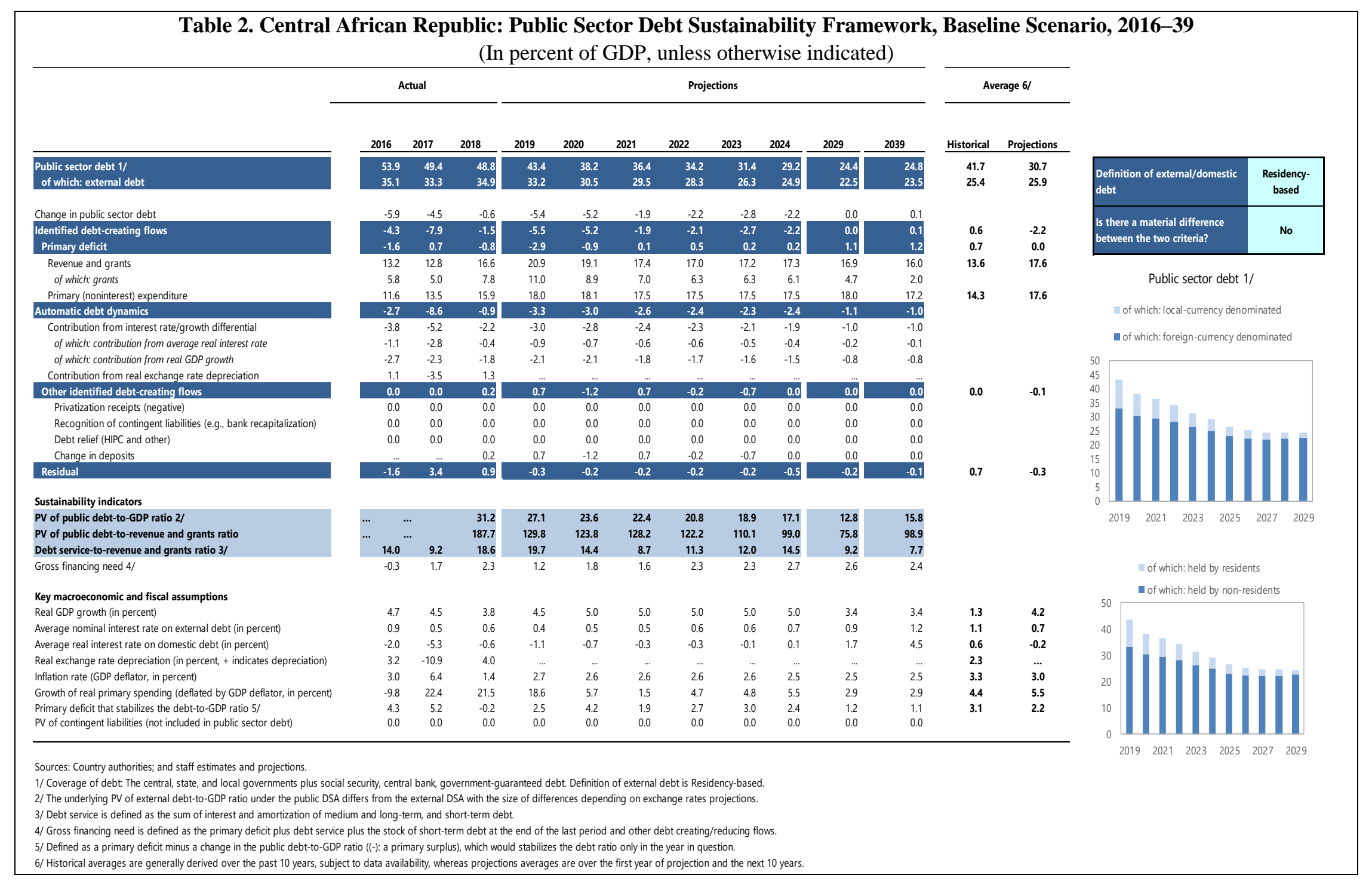




\section{Figure 1. Central African Republic: Indicators of Public and Publicly Guaranteed External Debt under Alternative Scenarios, 2019-29}
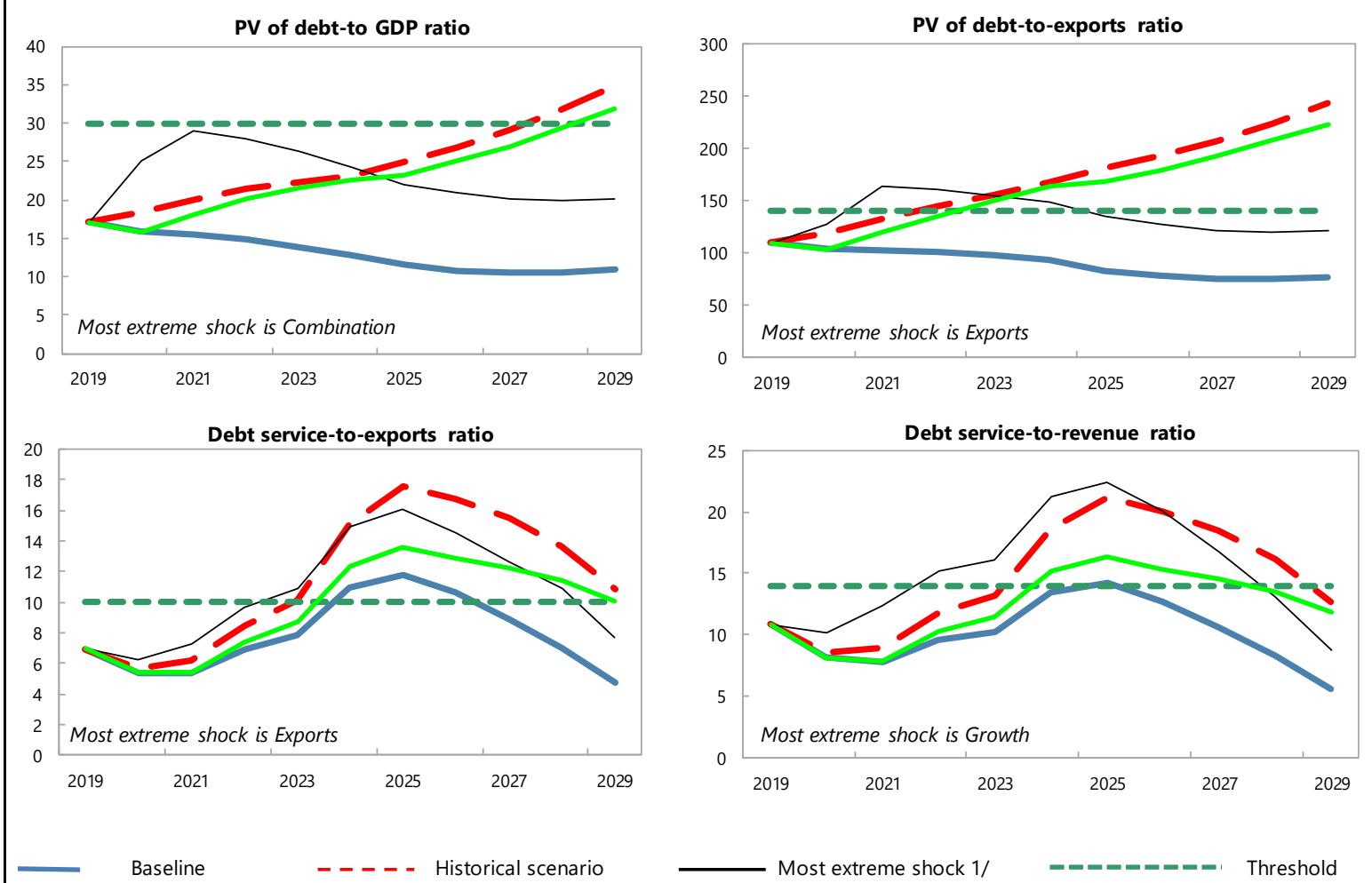

Low Grant Financing

\begin{tabular}{|c|c|c|}
\hline \multicolumn{3}{|c|}{ Customization of Default Settings } \\
\hline & Size & Interactions \\
\hline Standardized Tests & Yes & \\
\hline \multicolumn{3}{|l|}{ Tailored Tests } \\
\hline Combined CLs & Yes & \\
\hline Natural Disasters & n.a. & n.a. \\
\hline Commodity Prices ${ }^{2 /}$ & n.a. & n.a. \\
\hline Market Financing & n.a. & n.a. \\
\hline
\end{tabular}

\begin{tabular}{|c|c|c|}
\hline \multicolumn{3}{|c|}{ Borrowing Assumptions for Stress Tests* } \\
\hline & Default & User defined \\
\hline \multicolumn{3}{|l|}{ Shares of marginal debt } \\
\hline External PPG MLT debt & $100 \%$ & \\
\hline \multicolumn{3}{|l|}{ Terms of marginal debt } \\
\hline Avg. nominal interest rate on new borrowing in USD & $0.9 \%$ & $0.9 \%$ \\
\hline USD Discount rate & $5.0 \%$ & $5.0 \%$ \\
\hline Avg. maturity (incl. grace period) & 33 & 33 \\
\hline Avg. grace period & 6 & 6 \\
\hline
\end{tabular}

Note: "Yes" indicates any change to the size or interactions of the default settings for the stress tests. "n.a." indicates that the stress test does not * Note: All the additional financing needs generated by the shocks under the stress tests are assumed to be covered by PPG external MLT debt in the external DSA. Default terms apply.

Sources: Country authorities; and staff estimates and projections.

1/ The most extreme stress test is the test that yields the highest ratio in or before 2029. Stress tests with one-off breaches are also presented (if any), while these one-off breaches are deemed away for mechanical signals. When a stress test with a one-off breach happens to be the most exterme shock even after disregarding the one-off breach, only that stress test (with a one-off breach) would be presented.

2/ The magnitude of shocks used for the commodity price shock stress test are based on the commodity prices outlook prepared by the IMF research department. 
Figure 2. Central African Republic: Indicators of Public Debt Under Alternative Scenarios, 2019_ 29
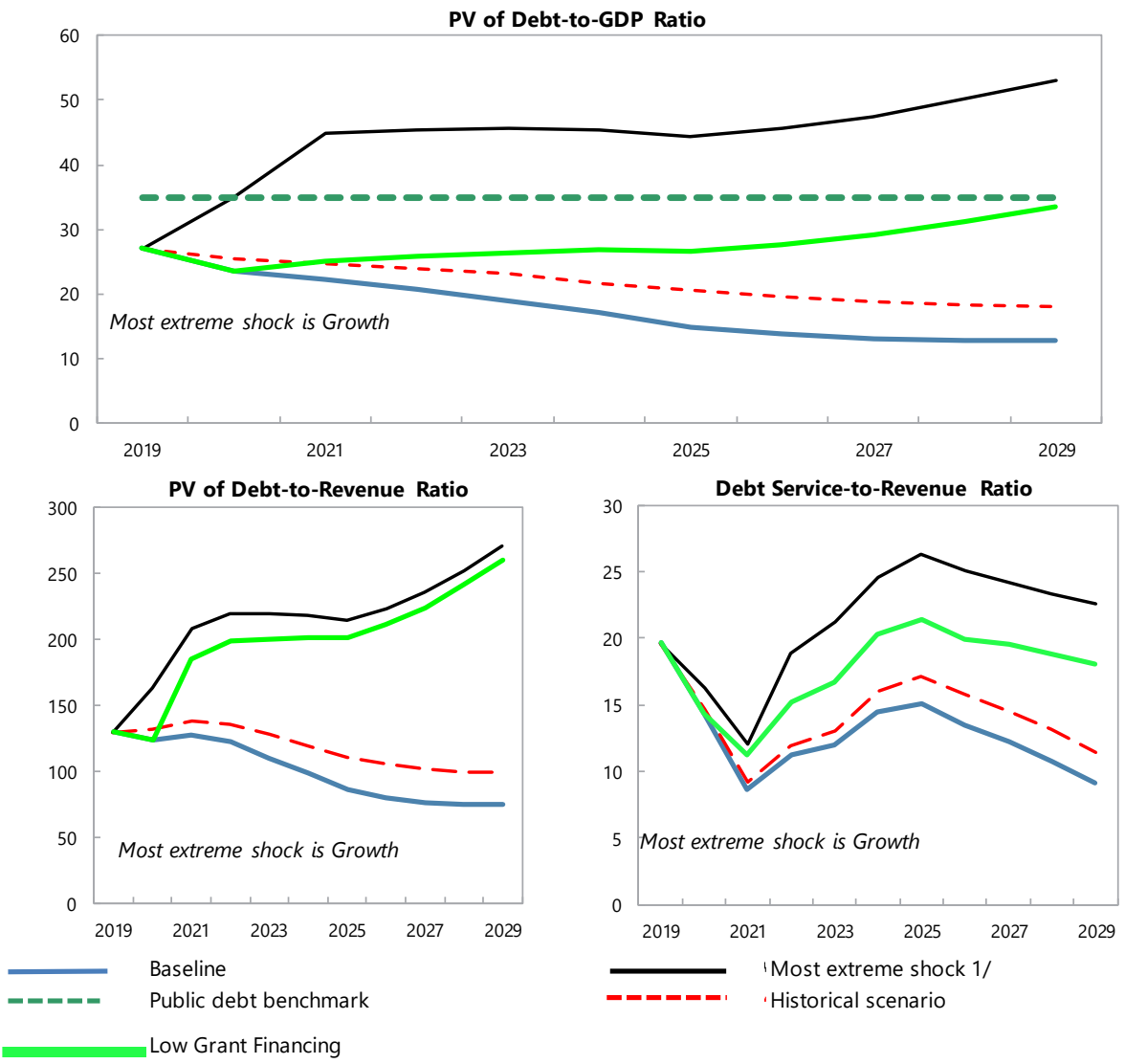

\begin{tabular}{|l|c|c|}
\hline \multicolumn{1}{|c|}{ Borrowing Assumptions for Stress Tests* } & Default & User defined \\
\hline Shares of marginal debt & & \\
External PPG medium and long-term & $85 \%$ & $85 \%$ \\
Domestic medium and long-term & $6 \%$ & $6 \%$ \\
Domestic short-term & $10 \%$ & $10 \%$ \\
\hline & & \\
\hline External MLT debt & $0.9 \%$ & $0.9 \%$ \\
Avg. nominal interest rate on new borrowing in USD & 33 & 33 \\
Avg. maturity (incl. grace period) & 6 & 6 \\
Avg. grace period & & $5.2 \%$ \\
Domestic MLT debt & $5.2 \%$ & 2 \\
Avg. real interest rate on new borrowing & 2 & 1 \\
Avg. maturity (incl. grace period) & 1 & $2.0 \%$ \\
Avg. grace period & & $1 \%$ \\
\hline Domestic short-term debt & & \\
Avg. real interest rate & & \\
\hline
\end{tabular}

* Note: The public DSA allows for domestic financing to cover the additional financing needs generated by the shocks under the stress tests in the public DSA. Default terms of marginal debt are based on baseline 10-year projections.

Sources: Country authorities; and staff estimates and projections.

$1 /$ The most extreme stress test is the test that yields the highest ratio in or before 2029. The stress test with a one-off breach is also presented (if any), while the one-off breach is deemed away for mechanical signals. When a stress test with a one-off breach happens to be the most exterme shock even after disregarding the one-off breach, only that stress test (with a one-off breach) would be presented. 


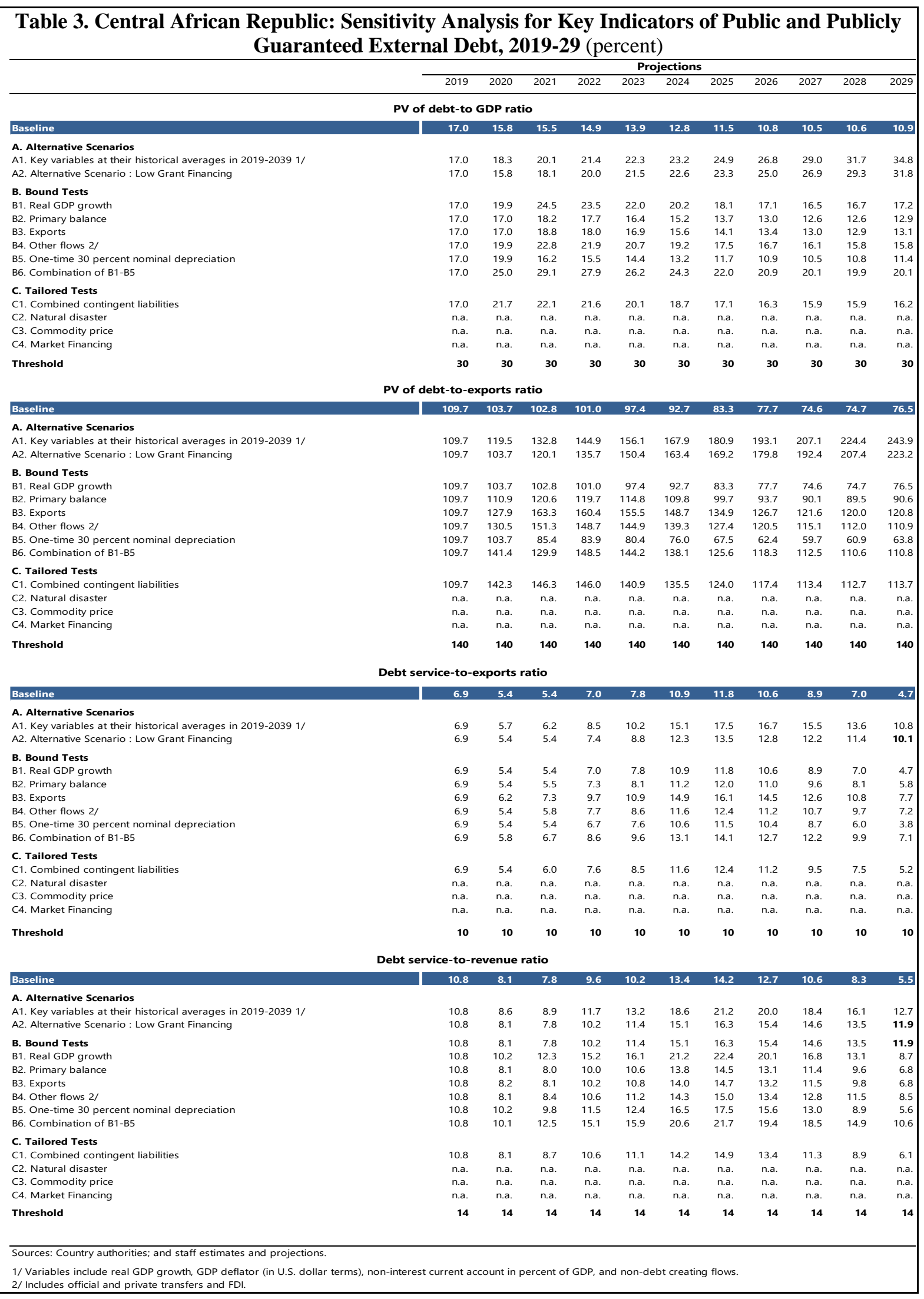


Table 4. Central African Republic: Sensitivity Analysis for Key Indicators of Public Debt, 2019-29

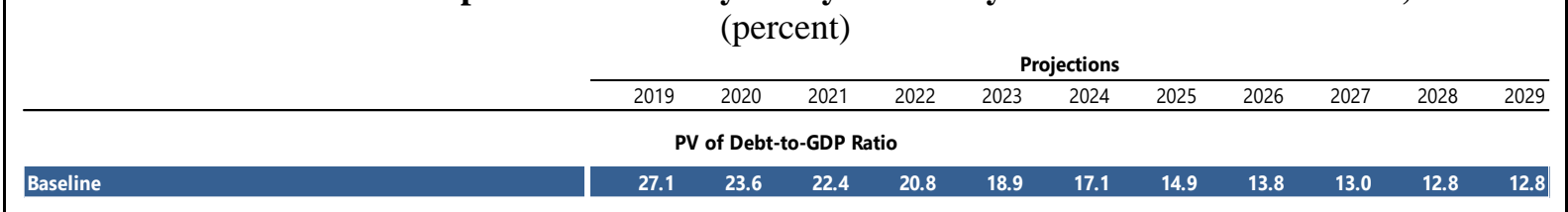

A. Alternative Scenarios

A1. Key variables at their historical averages in 2019-2039 1/

A2. Alternative Scenario : Low Grant Financing

$\begin{array}{lllllllllll}27 & 25 & 25 & 24 & 23 & 22 & 20 & 20 & 19 & 18 & 18\end{array}$

B. Bound Tests

B1. Real GDP growth

B2. Primary balance

B3. Exports

B4. Other flows 2/

B5. One-time 30 percent nominal depreciation

B6. Combination of B1-B5

C. Tailored Tests

C1. Combined contingent liabilities

C2. Natural disaster

C3. Commodity price

C4. Market Financing

Public debt benchmark

$\begin{array}{lllllllllll}27 & 24 & 25 & 26 & 26 & 27 & 27 & 28 & 29 & 31 & 33\end{array}$

Baseline

$\begin{array}{lllllllllll}27 & 35 & 45 & 45 & 46 & 45 & 44 & 46 & 47 & 50 & 53\end{array}$

$\begin{array}{lllllllllll}27 & 26 & 26 & 24 & 22 & 20 & 18 & 16 & 16 & 15 & 15\end{array}$

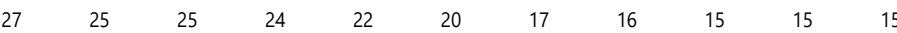

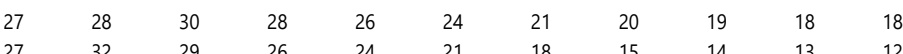

$\begin{array}{lllllllllll}27 & 32 & 29 & 26 & 24 & 21 & 18 & 15 & 14 & 13 & 12 \\ 27 & 27 & 29 & 27 & 25 & 24 & 21 & 20 & 19 & 18 & 18\end{array}$

A. Alternative Scenarios

A1. Key variables at their historical averages in 2019-2039 1/

A2. Alternative Scenario : Low Grant Financing

B. Bound Tests

B1. Real GDP growth

B2. Primary balance

B3. Exports

B4. Other flows 2/

B5. One-time 30 percent nominal depreciation

B6. Combination of B1-B5

C. Tailored Tests

C1. Combined contingent liabilities

C2. Natural disaster

C3. Commodity price

C4. Market Financing

\begin{tabular}{|c|c|c|c|c|c|c|c|c|c|c|}
\hline 27 & 32 & 30 & 28 & 26 & 24 & 21 & 20 & 19 & 18 & 18 \\
\hline n.a. & n.a. & n.a. & n.a. & n.a. & n.a. & n.a. & n.a. & n.a. & n.a. & n.a. \\
\hline n.a. & n.a. & n.a. & n.a. & n.a. & n.a. & n.a. & n.a. & n.a. & n.a. & n.a. \\
\hline n.a. & n.a. & n.a. & n.a. & n.a. & n.a. & n.a. & n.a. & n.a. & n.a. & n.a. \\
\hline
\end{tabular}

PV of Debt-to-Revenue Ratio

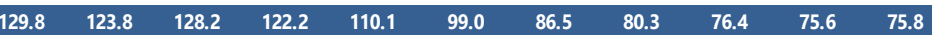

$\begin{array}{rrrrrrrrrrr}130 & 132 & 139 & 136 & 128 & 119 & 111 & 106 & 102 & 100 & 99\end{array}$

$\begin{array}{lllllllllll}19.666 & 14.4053 & 11.2866 & 15.2563 & 16.6601 & 20.342 & 21.4524 & 19.962 & 19.5191 & 18.7979 & 18.0228\end{array}$

$\begin{array}{rrrrrrrrrrr}130 & 164 & 208 & 219 & 219 & 218 & 215 & 224 & 236 & 252 & 270 \\ 130 & 135 & 147 & 140 & 128 & 116 & 102 & 96 & 91 & 90 & 89 \\ 130 & 129 & 145 & 139 & 126 & 114 & 101 & 94 & 90 & 88 & 88 \\ 130 & 145 & 170 & 164 & 149 & 136 & 122 & 115 & 110 & 107 & 105 \\ 130 & 174 & 172 & 161 & 145 & 125 & 105 & 93 & 83 & 77 & 73 \\ 130 & 139 & 155 & 148 & 136 & 128 & 114 & 107 & 103 & 103 & 103 \\ & & & & & & & & & & \\ 130 & 170 & 171 & 163 & 150 & 137 & 122 & 115 & 110 & 109 & 109 \\ \text { n.a. } & \text { n.a. } & \text { n.a. } & \text { n.a. } & \text { n.a. } & \text { n.a. } & \text { n.a. } & \text { n.a. } & \text { n.a. } & \text { n.a. } & \text { n.a. } \\ \text { n.a. } & \text { n.a. } & \text { n.a. } & \text { n.a. } & \text { n.a. } & \text { n.a. } & \text { n.a. } & \text { n.a. } & \text { n.a. } & \text { n.a. } & \text { n.a. } \\ \text { n.a. } & \text { n.a. } & \text { n.a. } & \text { n.a. } & \text { n.a. } & \text { n.a. } & \text { n.a. } & \text { n.a. } & \text { n.a. } & \text { n.a. } & \text { n.a. } \\ & & & & & & & & & & \end{array}$

Debt Service-to-Revenue Ratio

Baseline

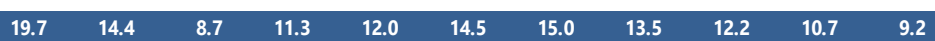

A. Alternative Scenarios

A1. Key variables at their historical averages in 2019-2039 1/

A2. Alternative Scenario : Low Grant Financing

B. Bound Tests

B1. Real GDP growth

B2. Primary balance

B3. Exports

B4. Other flows $2 /$

B5. One-time 30 percent nominal depreciation

B6. Combination of B1-B5

C. Tailored Tests

C1. Combined contingent liabilities

C2. Natural disaster

C3. Commodity price

C4. Market Financing

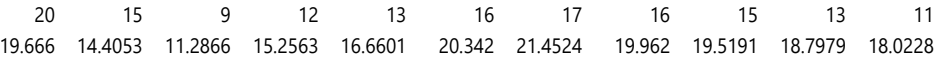

Sources: Country authorities; and staff estimates and projections.

1/ Variables include real GDP growth, GDP deflator and primary deficit in percent of GDP.

2 / Includes official and private transfers and FDI. 


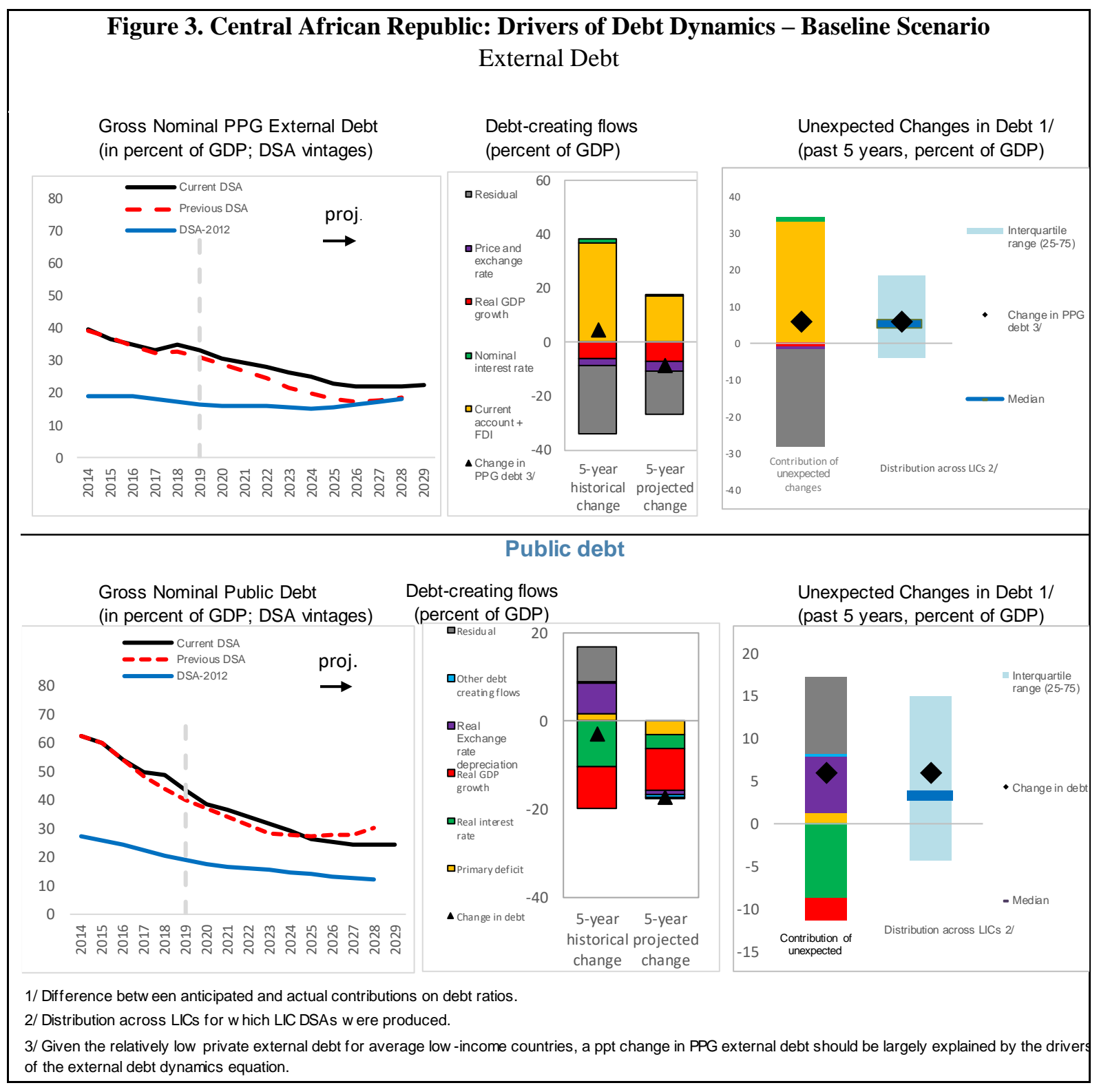




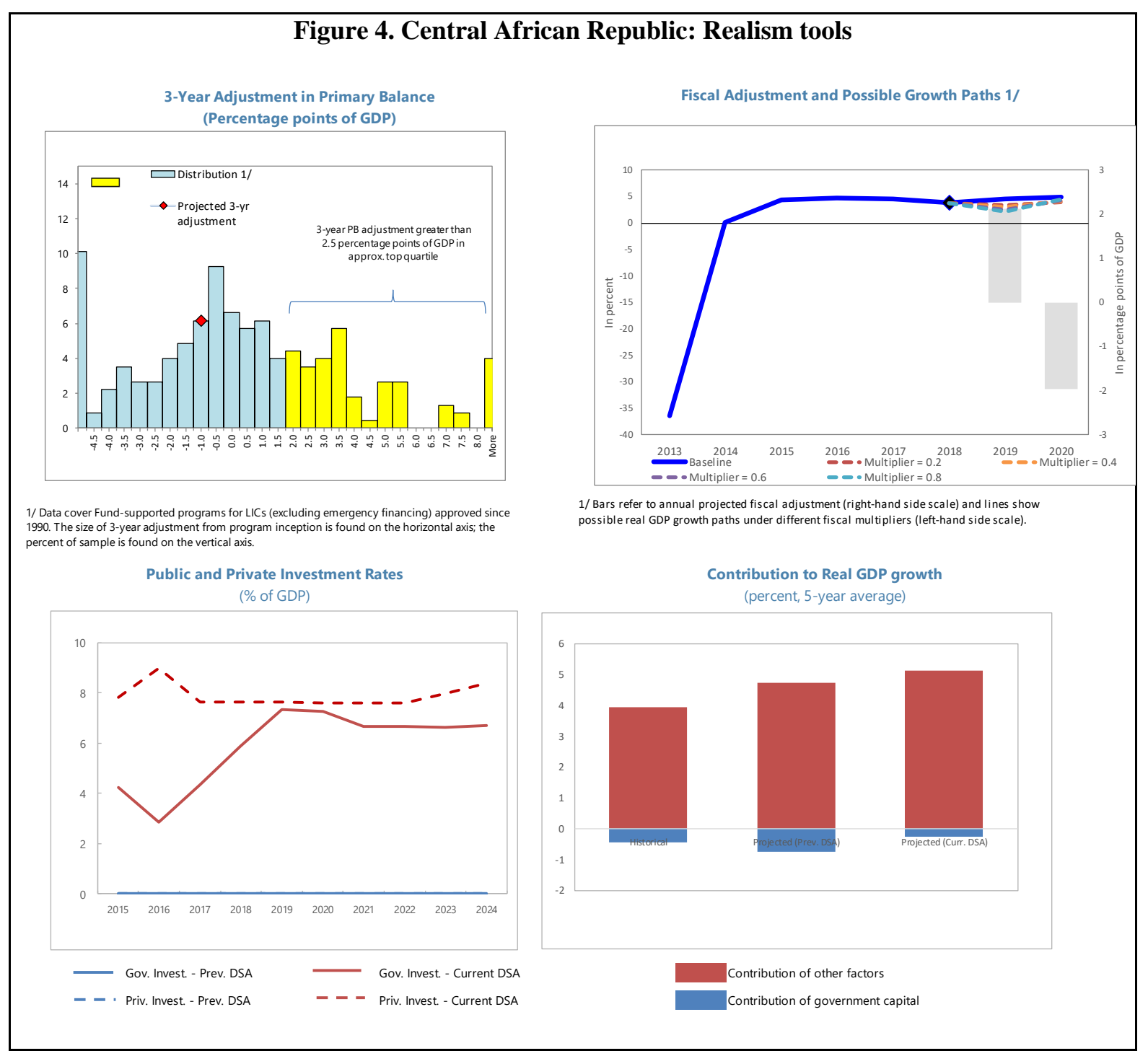

